\title{
Field Methods for Characterizing Weak Rock for Engineering
}

THE GEOLOGICAL SOCIETY OF AMERICA
PAUL M. SANTI

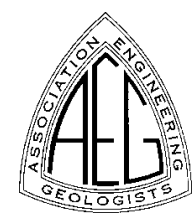

Department of Geological Engineering, Colorado School of Mines, Golden, CO 80401

Key Terms: Weak Rock, Weathered Rock, Shales, Field Testing

\section{ABSTRACT}

Many classification and testing methods for shale, slaking rock, weak rock, and weathered rock have been developed. However, few of these methods are suitable for field use or are applicable to a wide range of material types. The purpose of this paper is to present a summary of recent research and analysis evaluating classification and testing methods. This summary will assist the practitioner in properly identifying problem shale and weak rock units, in adequately describing their characteristics in the field, and in selecting and performing field tests to quantify their behavior. For identification of shale and weak rock units, three increasingly site-specific tools are presented. First is a map showing occurrences of weak rock units in the United States. Second is a detailed list of suspect rock types that may appear on regional or local geologic maps. Third is a summary of engineering properties that describe weak rock units, based on a review of technical literature. Some of these properties are compressive strengths between 1 and $20 \mathrm{MPa}$, slake durability less than 90 percent, clay content greater than 15 percent, poor induration, a significant amount (50 to 75 percent) of matrix between hard blocks, or high moisture content. Methods of field description were chosen based on a review of existing methods to assess their ease of application, breadth of application, and the usefulness of the engineering properties indicated by each system. Two modified methods are presented to indicate proportion and nature of corestones and matrix, strength, influence of discontinuities, and reactivity to water. Finally, field-testing methods that estimate strength, permeability, durability, and reaction to water are identified. These include point load index, Norwegian Geotechnical Institute Rock Mass Classification, jar slake, and hammer rebound classification. Predictive equations to estimate unconfined compressive strength, slake durability, and slake index are given.

\section{INTRODUCTION}

Throughout this paper, the term "weak rock" is used to refer both to weak and weathered materials. According to Santi and Doyle (1997), weak materials are "intact, unweathered to slightly weathered materials that have low compressive strength or are highly fractured." They defined weathered materials as "materials that show significant deterioration, particularly near the ground surface or along fractures." Santi and Doyle (1997) also note, "although these types of materials show markedly different genetic and post-depositional histories, they both represent a range of properties intermediate to soil and rock." This observation could lead one to group weak and weathered materials together for analysis and discussion.

In spite of the large number of classification and testing schemes for shales and other weak or weathered rock types, there exists no single accepted method for characterizing these materials. For example, researchers and practicing professionals who deal with weak rock were asked at a symposium to suggest the classification system they prefer to use. Among 10 respondents, nine different schemes were suggested (Santi and Shakoor, 1997). In an overview of classification systems, Chapman and others (1976) note that shale classification systems have fallen into three categories: systems developed by geologists emphasizing genesis, systems developed by engineers emphasizing quantitative laboratory tests, and systems developed by agencies, which prove to be limited to specific regions or applications.

In particular, field recognition and field identification of adverse properties need to be consistently addressed. Santi and Shakoor (1997) note that many common shortcomings in dealing with weak rocks stem from poor field data, lack of recognition of sensitivity to water, and underestimation of the influence of rock mass properties such as remnant bedding planes. The goal of this paper is to help reduce these shortcomings by summarizing recent research and analysis for field identification, description, and testing of weak and weathered rock materials. The content of this paper is expanded and updated from Santi (1998a).

\section{IDENTIFICATION OF WEAK ROCK}

For field identification of weak rock units, three increasingly site-specific tools are presented. The first is 


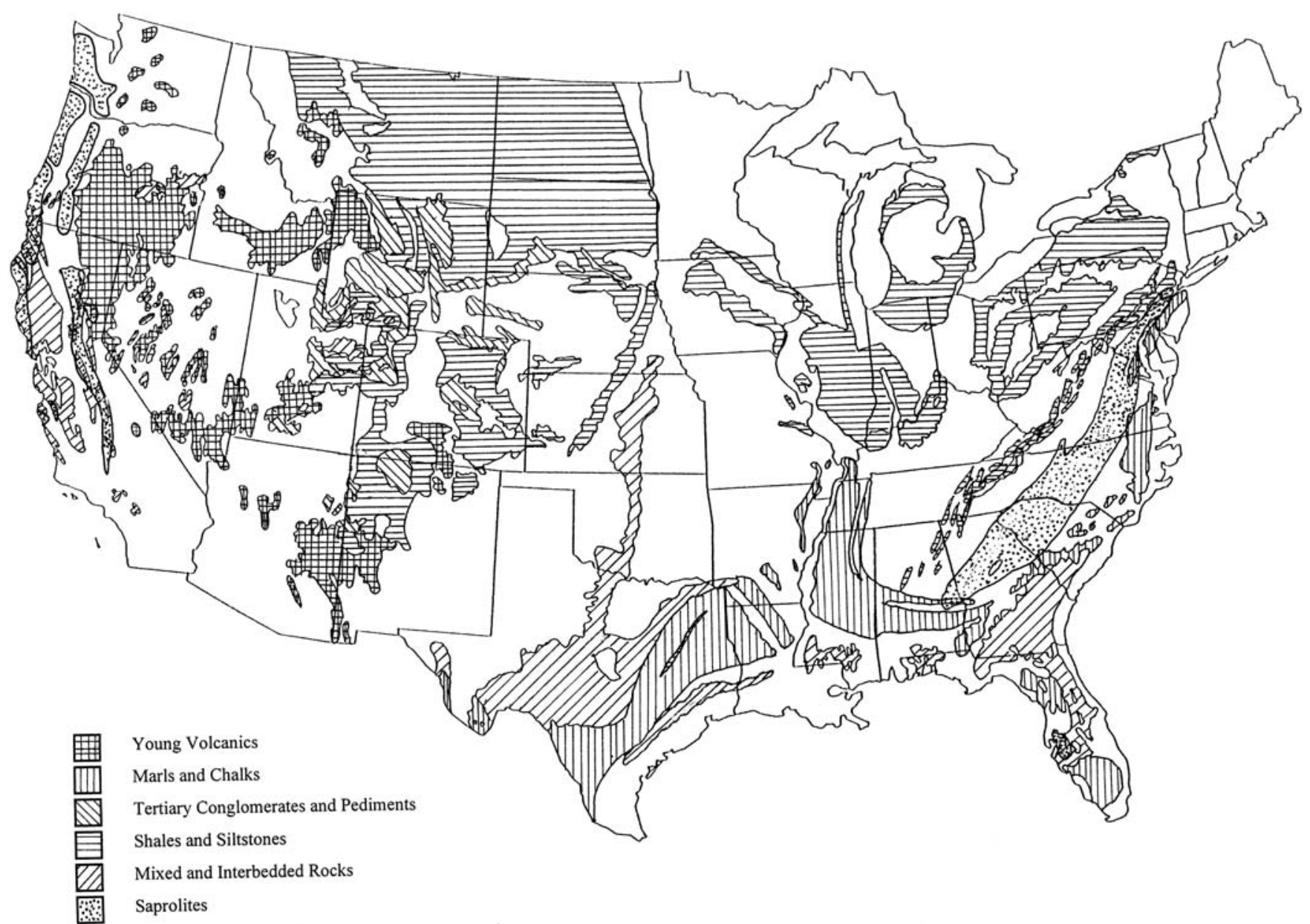

Figure 1. Examples of weak rock occurrences in the conterminous United States (from Santi and Doyle, 1997). Units of small areal extent are not included because of map scale limitations. Units shown are expected to have less than $30 \mathrm{ft}$ of soil cover and to be at least $10 \mathrm{ft}$ thick.

a map showing locations of weak rock units in the United States. The second is a detailed list of suspect rock types that may appear on regional or local geologic maps. The third is a summary of engineering properties that describe weak rock units, based on a review of technical literature.

\section{General Weak Rock Units}

Figure 1 (from Santi and Doyle, 1997) shows generalized locations of various types of weak rock in the United States. Because of the small scale of the map, many small weak rock bodies could not be included. Likewise, karst formations were not included because their properties depend so strongly on microclimate and other local conditions (Santi and Doyle, 1997). The units shown in Figure 1 are expected to have less than $30 \mathrm{ft}$ (10 $\mathrm{m})$ of soil cover and to be at least $10 \mathrm{ft}(3 \mathrm{~m})$ thick. The discussion of each type of weak rock below has been summarized from Santi and Doyle (1997).

The young volcanic units shown in Figure 1 consist mostly of lava flows and ash beds in the Cascade Range, the Snake River basalts and related tuffs, and Tertiary tuffs and volcanic breccias in the Basin and Range Province and in the Mexican Highlands. These materials are considered weak rock because of their low strength, interbedding with continental detritus, and susceptibility to weathering and alteration as a result of their young ages. Some portions may be dominated by stronger and more resistant units.

Marls and chalks are included in Figure 1 because their high calcium carbonate contents render them susceptible to dissolution, softening, or expansion in the presence of water. These materials are also often poorly consolidated, resulting in low strength. They are concentrated in the Atlantic and Gulf Coastal Plain and include the Navarro, Yorktown, and Calvert Formations; the Taylor Marl and the Austin Chalk; and the Jackson, Claiborne, Wilcox, and Midway Groups, among others.

The Tertiary conglomerates and pediments are formed from accumulations of continentally derived sediments. They contain a high percentage of easily weathered minerals such as micas and feldspars because of their 
Field Characterization of Weak Rock

Table 1. Types of weak rocks (compiled with data from Santi and Doyle, 1997).

Mineralogy or Processes Affecting $\quad$ Explanation of Importance Rock Types

Mineralogy or Processes Affecting

Materials with high clay content

Materials with other undesirable minerals

Young materials

Highly weathered materials

Metamorphosed materials

Hardened soils
Clay minerals are very sensitive to water, have low friction angles, and are generally poorly cemented, all of which reduce material strength. Although an engineering definition of clay requires at least 50 percent clay-sized particles, clay-like behavior will be observed with a much smaller clay component.

Other minerals may be weak or reactive to water.

Young materials may be poorly cemented, poorly consolidated, and retain a significant component of unstable and easily weathered minerals.

Weathering removes cement, dissolves mineral framework, loosens cohesive bonds, creates clays, lower friction angles, yet often leaves relict planes of weakness such as joints and bedding planes. Weathering also deposits clays on fractures and separates fractures.

Metamorphism often produces unstable and easily weathered minerals, schistosity or other layered weakness planes, or block-in-matrix structure which is problematic for sampling and testing.

These materials are often underlain by weaker soils, and they may also break down upon extended saturation.
Overconsolidated clay; cemented clayshale, shale; siltstone; mudstone, mudrock; tightly interbedded sedimentary rocks; marl; flysch; turbidite

Chalk; anhydrite; gypsum

Quaternary carbonates; Tertiary sedimentary rocks (conglomerate, sandstone); Tertiary volcanic rocks (some basalt, tuff, volcanic breccia); pediments

Saprolite; weathered igneous rocks; weathered metamorphic rocks

Melange; metashale

Hardpan; caliche; laterite; tropical duracrust proximity to the source areas. Weathering of these minerals, compounded by the poor consolidation and cementation typical of young rocks, results in low strength. These units include the White River Group, Wasatch Formation, and Castle Rock Conglomerate of the western Great Plains and Colorado Plateau provinces.
Shales and siltstones are the most widespread and frequently encountered weak rock types, as shown on Figure 1 . They are commonly poorly compacted and cemented, exhibit low strength values, slake on contact with water, may experience rebound or expansion as a result of stress relief, and may be interbedded with undesirable materials

Table 2. Summary of engineering properties of weak rock (modified from Santi and Doyle, 1997).

\begin{tabular}{|c|c|c|}
\hline Test or Property & Value or Range for Weak Rock & Reference \\
\hline Compressive strength & $1-20 \mathrm{MPa}$ & Afrouz, 1992 \\
\hline Standard penetration test & $50-300$ blows per $\mathrm{ft}$ ( $15-90$ blows per $\mathrm{m})$ & $\begin{array}{l}\text { White and Richardson, } 1987 \\
\text { Sowers, } 1973\end{array}$ \\
\hline Rock quality designation & $<25-75$ percent & Santi and Doyle, 1997 \\
\hline Hammer rebound & $\geq$ category 4 & Santi, 1995 \\
\hline Seismic wave velocity & $<7,000 \mathrm{ft}$ per second $*(2100 \mathrm{~m} / \mathrm{sec})$ & $\begin{array}{l}\text { Caterpillar, } 1996 \\
\text { White and Richardson, } 1987\end{array}$ \\
\hline Ratio of weathered matrix to unweathered blocks & $>75$ percent matrix & Geological Society, 1995 \\
\hline Jar slake & $\leq 4$ & Santi, 1995 \\
\hline Slake durability, $\mathrm{I}_{\mathrm{d}}(2)$, ASTM D4644-87 & $<90$ percent & $\begin{array}{l}\text { Santi and Doyle, } 1997 \\
\text { Lee and de Freitas, } 1989\end{array}$ \\
\hline Free swell & $>3-4$ percent & $\begin{array}{l}\text { Welsh and others, } 1991 \\
\text { Underwood, } 1967\end{array}$ \\
\hline Natural moisture content & $\begin{array}{l}>1 \text { percent for igneous and metamorphic rocks } \\
>5-15 \text { percent for clayey rocks }\end{array}$ & Santi and Doyle, 1997 \\
\hline Dearman weathering classification & $\geq$ category 4 & Santi, 1995 \\
\hline CSIR rock mass rating (Bieniawski, 1976) & $<35-60$ & Santi, 1995 \\
\hline Norwegian Geotechnical Institute "Q" rating & $<2$ & Santi, 1995 \\
\hline
\end{tabular}

*Lower velocities may be appropriate, depending on equipment used and degree of rock fracturing. 
Table 3. Weathering grades of weak and weathered rock (modified from Dearman, 1976; and Geological Society, 1995).

\begin{tabular}{|c|c|c|c|}
\hline \multirow[b]{2}{*}{ Weathering Grade } & \multirow[b]{2}{*}{ General Description } & \multicolumn{2}{|c|}{ Specific Description } \\
\hline & & Weathered Materials* & Weak Rock Materials $\dagger$ \\
\hline VI — Residual soil & $\begin{array}{l}\text { The rock is completely changed to } \\
\text { a soil in which the original rock } \\
\text { texture has been completely } \\
\text { destroyed. }\end{array}$ & $\begin{array}{l}\text { Soil derived by in situ weathering } \\
\text { but retaining none of the original } \\
\text { texture or fabric. }\end{array}$ & $\begin{array}{l}\text { Residual or reworked. Matrix with } \\
\text { occasional altered random or } \\
\text { "apparent" lithorelics, bedding } \\
\text { destroyed. }\end{array}$ \\
\hline $\mathrm{V}$ - Completely decomposed & $\begin{array}{l}\text { The rock is changed to soil in } \\
\text { which the original rock texture is } \\
\text { (mainly) preserved. }\end{array}$ & $\begin{array}{l}\text { Considerably weakened, slakes, } \\
\text { and the original texture is apparent. }\end{array}$ & $\begin{array}{l}\text { Destructured. Greatly weakened, } \\
\text { mottled, ordered lithorelicts in } \\
\text { matrix becoming weakened and } \\
\text { disordered, bedding disturbed. }\end{array}$ \\
\hline IV — Highly decomposed & $\begin{array}{l}50-100 \text { percent soil from } \\
\text { decomposition of the rock mass. }\end{array}$ & $\begin{array}{l}\text { Large pieces can be broken by } \\
\text { hand; does not readily slake when } \\
\text { dry sample immersed in water. }\end{array}$ & $\begin{array}{l}\text { Partially or distinctly weathered. } \\
\text { Weakened, close fracture } \\
\text { spacing, weathering penetrating } \\
\text { in from fractures, brown } \\
\text { oxidation. }\end{array}$ \\
\hline III - Moderately decomposed & $\begin{array}{l}\text { Up to } 50 \text { percent soil from } \\
\text { decomposition of the rock mass. }\end{array}$ & $\begin{array}{l}\text { Considerably weakened, } \\
\text { penetrative discoloring; large } \\
\text { pieces cannot by broken by hand. }\end{array}$ & $\begin{array}{l}\text { Unweathered. Original strength, } \\
\text { color, and fracture spacing. }\end{array}$ \\
\hline II — Slightly decomposed & $\begin{array}{l}100 \text { percent rock; discontinuity } \\
\text { surfaces or rock material may be } \\
\text { discolored. }\end{array}$ & $\begin{array}{l}\text { Slight discoloration and slight } \\
\text { weakening. }\end{array}$ & - \\
\hline I - Fresh & $\begin{array}{l}100 \text { percent rock; no discoloration, } \\
\text { decomposition, or other change. }\end{array}$ & Unchanged from original state. & - \\
\hline
\end{tabular}

*Uniform weathered materials such as igneous and metamorphic rocks, which may show weakening and susceptibility to slaking on weathering. $\dagger$ Materials that incorporate both matrix and mass features; weathering is enhanced along fractures, but most weathering occurs near the ground surface. Includes overconsolidated clays, shales, and mudstones.

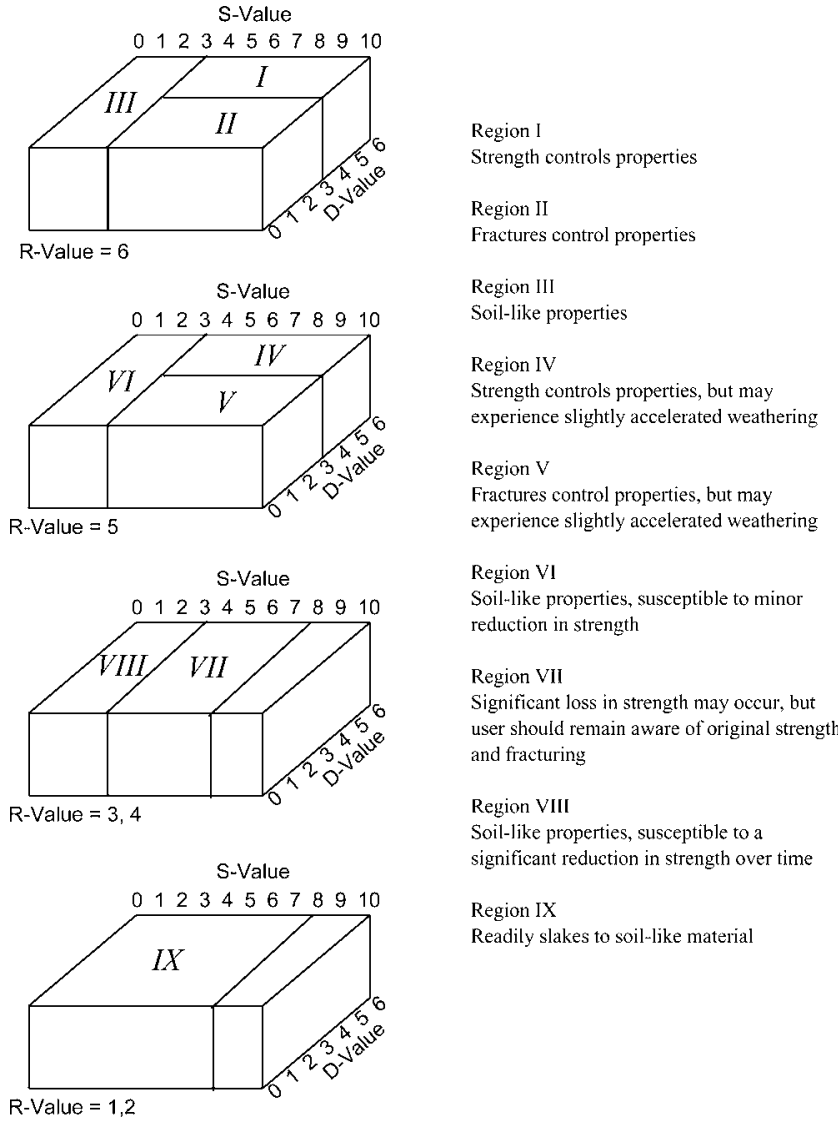

Figure 2. Interpretation of S-D-R (strength-discontinuity-rate of change of strength) values from Table 4 (modified from Palicki, 1997). such as evaporites, bentonite, or high-organic-content materials. In general, the shales and siltstones in the western United States are Cretaceous age or younger and include the Pierre, Fort Union, and Bearpaw shales, among others. The shales of the Midwest and Eastern United States are mostly Triassic age or older and include dozens of formations grouped together in Figure 1.

The mixed and interbedded rocks shown in Figure 1 include materials that could be placed in more than one category, such as marly shales, in addition to typical mixed materials, such as flysch, turbidites, and mélange. The best-known unit in this group is the Franciscan Complex in California, Nevada, and Oregon.

Saprolites are residual soils formed on deeply weathered rocks and ordinarily retain the original structure of the parent rock. The units shown in Figure 1 include phosphate clays of central Florida and extensive saprolite exposures on the Piedmont Plateau, the Atlantic Coastal Plain, the northern Pacific Coast, and portions of the Sierra Nevada and Cascade Ranges.

\section{Rock Types for Local Recognition}

Figure 1 is intended to provide a regional scale reference for various types of weak rock. Local geologic maps should be used to identify the actual types and boundaries of weak rock in an area. The rock types that are typically weak are listed in Table 1 (more detail on 
Table 4. Corestone $(C)$, strength $(S)$, discontinuity $(D)$, and rate of change of strength $(R)$ values for weak and weathered rock $(m o d i f i e d$ from Geological Society, 1995; and Palicki, 1997).

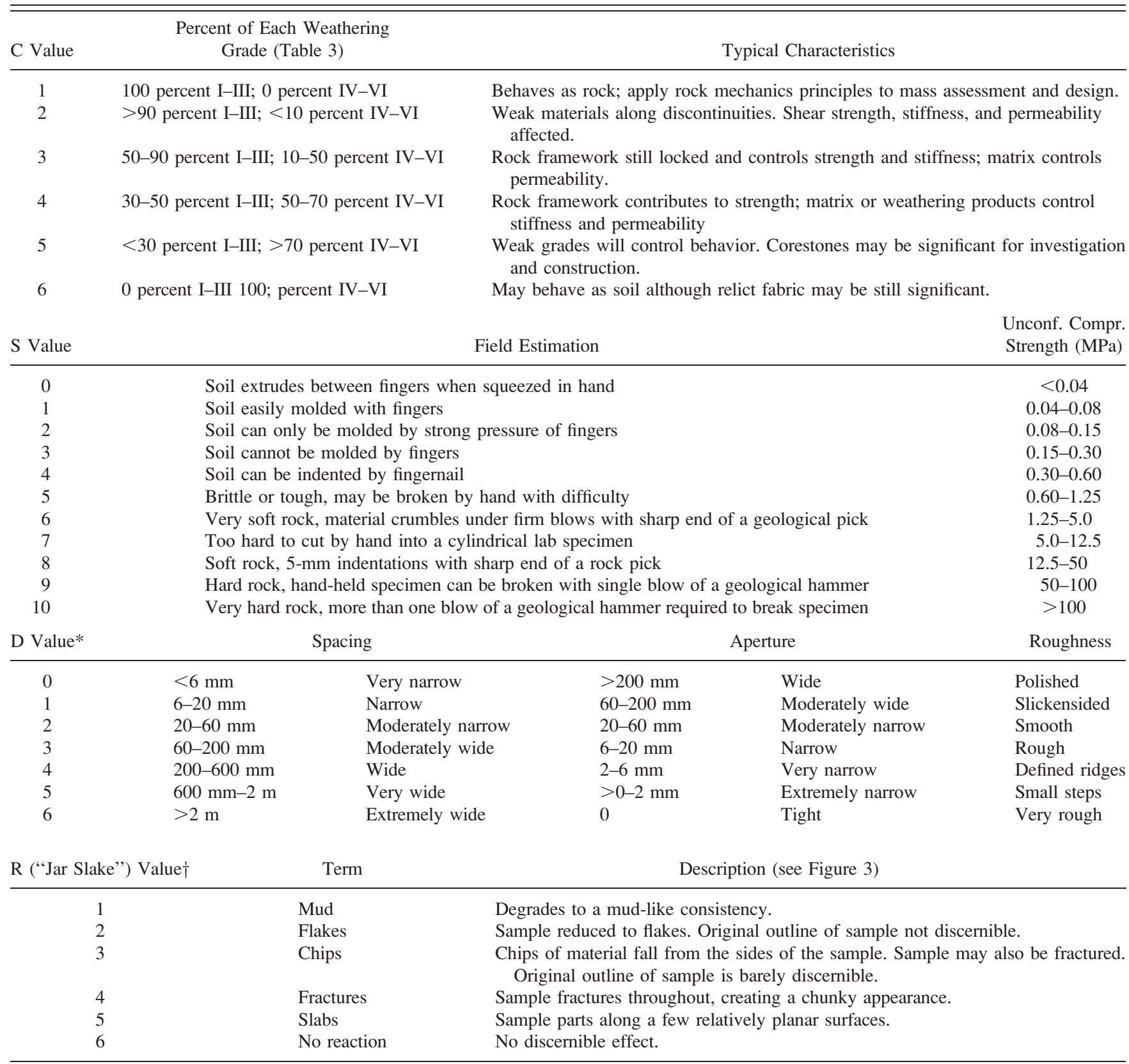

*Select the lowest "D" value from the three factors (spacing, aperture, or roughness).

$\dagger$ These values are based on reactions after a 30 -minute soaking in distilled water.

some of these rock types, as well as several case histories, are given in Hatheway, 1997).

Rock types in Table 1 are grouped by both mineral content and post-depositional processes because both of these components contribute to weak rock behavior. Poorly behaving minerals include clays, evaporites, certain carbonates, and unstable minerals produced at high temperature and pressure (these are metamorphic minerals, such as olivine, pyroxene, amphibole, biotite, and calcium- rich feldspar). Post-depositional processes contributing to weak rock formation include slaking or dissolution in water, weathering, poor cementation and consolidation, development of planes of weakness, and proximity to other layers with substantially different properties.

\section{Recognition of Weak Rock by Engineering Properties}

If even a small amount of laboratory or field data are 
Table 5. Engineering behavior from weathering grade (modified from Dearman et al, 1978; Krank and Watters, 1983; Lee and de Freitas, 1989; and Santi, 1995).

\begin{tabular}{|c|c|c|c|}
\hline Engineering Property & Fresh, I & Slightly Weathered, II & Moderately Weathered, III \\
\hline Foundation conditions & $\begin{array}{l}\text { Suitable for concrete and earthfill } \\
\text { dams }\end{array}$ & $\begin{array}{l}\text { Suitable for concrete and earthfill } \\
\text { dams }\end{array}$ & $\begin{array}{l}\text { Suitable for small concrete structures, } \\
\text { earthfill dams }\end{array}$ \\
\hline Excavatability & In general, blasting necessary & In general, blasting necessary & $\begin{array}{l}\text { Generally blasting needed, but ripping } \\
\text { may be possible } \\
\text { depending upon the jointing intensity }\end{array}$ \\
\hline Building material & $\begin{array}{l}\text { Very durable, difficult } \\
\text { to shape, excellent aesthetic } \\
\text { properties, good aggregate }\end{array}$ & $\begin{array}{l}\text { Very durable, but less } \\
\text { aesthetically pleasing due to } \\
\text { discoloration, good aggregate }\end{array}$ & $\begin{array}{l}\text { Poor, subject to deterioration, not } \\
\text { suitable as an aggregate }\end{array}$ \\
\hline $\begin{array}{l}\text { Slope stability } \\
\text { (Krank and Watters, 1983) }\end{array}$ & $\begin{array}{l}\text { Excellent; can stand } \\
\text { vertically unsupported }\end{array}$ & $\begin{array}{l}\text { Excellent; can stand } \\
\text { vertically unsupported }\end{array}$ & $\begin{array}{l}\text { Very good; can stand vertically } \\
\text { unsupported, but subject to deterioration }\end{array}$ \\
\hline \multirow{2}{*}{$\begin{array}{l}\text { Slope stability } \\
\text { (Dearman, et al, 1978) }\end{array}$} & 1/4:1 H:V & $1 / 2: 1$ to $1: 1 \mathrm{H}: \mathrm{V}$ & $1: 1 \mathrm{H}: \mathrm{V}$ \\
\hline & \multicolumn{3}{|c|}{$\begin{array}{l}\text { Benches and surface protection structures are advisable, particularly for more highly weathered material. } \\
\text { The presence of through-going adversely oriented structures is not taken into account. }\end{array}$} \\
\hline Tunnel support & $\begin{array}{l}\text { Not required unless joints } \\
\text { are closely spaced or } \\
\text { adversely oriented }\end{array}$ & $\begin{array}{l}\text { Not required unless joints } \\
\text { are closely spaced or } \\
\text { adversely oriented }\end{array}$ & Light steel sets on 0.6 - to $1.2-\mathrm{m}$ centers \\
\hline Point load strength $(\mathrm{MPa})$ & $9-18$ & $5-12.5$ & $2-6$ \\
\hline Schmidt hammer value (MPa) & $59-62$ & $51-56$ & $37-48$ \\
\hline Moisture content (percent) & $0.06-0.30$ & $0.15-0.29$ & $0.25-0.49$ \\
\hline $\begin{array}{l}\text { Unconfined compressive } \\
\text { strength }(\mathrm{MPa})\end{array}$ & $125-260$ & $100-175$ & $60-120$ \\
\hline Drilling RQD (percent) & 75 , usually 90 & 75 , usually 90 & $50-75$ \\
\hline Core recovery (percent) (NX) & 90 & 90 & 90 \\
\hline $\begin{array}{l}\text { Drilling rates }(\mathrm{m} / \text { hour }) \\
\text { (Diamond } \mathrm{NX})\end{array}$ & $2-4$ & $2-4$ & $8-10$ \\
\hline $2 \frac{1}{2}$ in. percussion & $5-7$ & 8 & $12-15$ \\
\hline Permeability & Low to medium & Medium to high & Medium to high \\
\hline Seismic velocity $(\mathrm{m} / \mathrm{sec})$ & $3050-5500$ & $2500-4000$ & $1500-3000$ \\
\hline Resistivity (ohm-m) & 340 & $240-540$ & $180-240$ \\
\hline
\end{tabular}

available, it may be used to help identify problematic weak rocks. While the map and rock type information presented above is useful as a general overview for a region, the engineering properties should be used for site-specific confirmation. A summary of engineering properties potentially identifying weak rock is given in Table 2 .

Details on the selection of ranges and cutoff values in Table 2 are given in Santi and Doyle (1997). In general, these ranges and cutoff values recognize the influence of fractures, decreased strength, creation of weathered matrix material, and reaction to water demonstrated by weak and weathered rock materials. For example, soil-like materials will typically have strength values below the ranges shown for compressive strength, standard penetration test, rock quality designation, and hammer rebound, and rock-like materials will have values above these ranges. As intact rock weathers, seismic wave velocity drops $(7,000 \mathrm{ft}$ per second $[2,100 \mathrm{~m} / \mathrm{second}]$ is judged to be a suitable threshold related to conventional rippability for a D9 bulldozer, according to Caterpillar, 1996). Furthermore, the volume of fine-grained weathered matrix material increases to the point that the matrix, rather than the intact rock blocks in between, controls the behavior (at approximately 75 percent matrix). Material with high reaction to water and low resistance to abrasion is considered weak (measured by low jar slake values, low slake durability, and high free swell). High natural moisture contents also indicate a high degree of weathering, fracturing, or disaggregation. Finally, weak rocks will plot toward one end of many rock classification schemes (schemes by NGI [Barton et al. 1974], Dearman [1976], and Bieniawski [1976] are suggested here). Not all of the criteria shown in Table 2 are equally diagnostic for different rock types, and some very strong rocks will 
Table 5. Extended

\begin{tabular}{|c|c|c|}
\hline Highly Weathered, IV & Completely Weathered, V & Residual Soil, VI \\
\hline Suitable for earthfill dams & Suitable for low earthfill dams & Generally unsuitable \\
\hline $\begin{array}{l}\text { Generally ripping and/or } \\
\text { scraping necessary }\end{array}$ & Scraping & Scraping \\
\hline $\begin{array}{l}\text { Unsuitable, not usable as } \\
\text { an aggregate }\end{array}$ & $\begin{array}{l}\text { Too angular and poorly graded to serve } \\
\text { as an aggregate by itself }\end{array}$ & $\begin{array}{l}\text { Too poorly graded to be used as an aggregate by } \\
\text { itself, but may serve as a sand filler if screened }\end{array}$ \\
\hline $\begin{array}{l}\text { Good; can stand vertically unsupported } \\
\text { up to } 25 \text { feet high, greater heights } \\
\text { should be } 1: 1 \mathrm{H}: \mathrm{V} \text { with benches, } \\
\text { deteriorates with time }\end{array}$ & $\begin{array}{l}\text { Moderate; can stand unsupported at } 1: 1 \mathrm{H}: \mathrm{V} \\
\text { with benches to catch detritus }\end{array}$ & $\begin{array}{l}\text { Very poor; unstable because of low cohesion, greatly } \\
\text { influenced by ground water, best removed }\end{array}$ \\
\hline \multirow[t]{2}{*}{$1: 1$ to $1.5: 1 \mathrm{H}: \mathrm{V}$} & $1.5: 1$ to $2: 1 \mathrm{H}: \mathrm{V}$ & $1.5: 1$ to $2: 1 \mathrm{H}: \mathrm{V}$ \\
\hline & \multicolumn{2}{|c|}{$\begin{array}{l}\text { Benches and surface protection structures are advisable, particularly for more highly weathered material. } \\
\text { The presence of through-going adversely oriented structures is not taken into account. }\end{array}$} \\
\hline $\begin{array}{l}\text { Steel sets, partial lagging, } \\
0.6-\text { to } 0.9-\mathrm{m} \text { centers }\end{array}$ & $\begin{array}{l}\text { Heavy steel sets, complete lagging on } 0.6 \text { - to } \\
0.9 \text {-m centers. If tunneling below water table, } \\
\text { possibility of soil flow into tunnel }\end{array}$ & $\begin{array}{l}\text { Heavy steel sets, complete lagging on } 0.6-\text { to } 0.9-\mathrm{m} \\
\text { centers. If tunneling below water table, possibility } \\
\text { of soil flow into tunnel }\end{array}$ \\
\hline $0.3-0.9$ & $0.1-0.5$ & - \\
\hline $12-21$ & $5-20$ & - \\
\hline $0.37-3.80$ & $7.84-21.00$ & $12.24-22.1$ \\
\hline $35-55$ & $1-10$ & $<1$ \\
\hline $0-50$ & 0 or does not apply & 0 or does not apply \\
\hline $\begin{array}{l}15 \text { to } 70 \text {, depending on percentage } \\
\text { of corestones }\end{array}$ & 15 as sand & 15 as sand \\
\hline $8-10$ & $10-13$ & $10-13$ \\
\hline $12-15$ & 17 & 17 \\
\hline High & Medium & Low \\
\hline 1000-2000 & $500-1000$ & $500-1000$ \\
\hline $180-240$ & 180 & 180 \\
\hline & Tends to be determined by joint openness and wa & -table depth \\
\hline
\end{tabular}

exhibit some properties in the weak rock range. Identification of weak rock using Table 2 should be made on the basis of more than one type of test, if possible.

\section{FIELD DESCRIPTION OF WEAK ROCK}

Santi (1997) evaluates and compares 14 different popular classification systems for weak or weathered rock and proposes modifications to enhance the applicability of some of the more useful systems. The evaluation was based on a series of 10 questions, which should be answered "yes" for the most useful systems:

1. Can it (the system) be applied in the field without special equipment?

2. Can it be used without any laboratory work?

3. Is the classification confirmed and enhanced with laboratory data?

4. Does it apply to weak rock?
5. Does it apply to weathered rock?

6. Does it apply to rock masses, considering fractures and block-in-matrix structure?

7. Does it evaluate strength?

8. Does it evaluate durability?

9. Does it suggest a range of quantitative engineering properties?

10. If not quantitative, does it suggest at least a qualitative range of engineering properties?

Although no single system addresses all the issues queried above, Santi (1997) suggests that modifications to Dearman (1976), Geological Society (1995), and Palicki (1997) may be incorporated and the systems used in tandem to provide a thorough and useful field classification system. For this paper, Santi's (1997) system has been further modified and consolidated and is presented in Tables 3 and 4.

To apply Table 3, the user should first identify the 
Table 6. Estimates of slake durability and long-term material behavior based on the rate of change of strength $(R)$ value (compiled with data from Santi and Higgins, 1998; and Santi, 1995).

\begin{tabular}{cccl}
\hline \hline $\begin{array}{c}\text { (R) Value } \\
\text { ("Jar Slake" } \\
\text { Category) }\end{array}$ & $\begin{array}{c}\text { Slake } \\
\text { Durability }\end{array}$ & $\begin{array}{c}\text { Slake } \\
\text { Index }\end{array}$ & \multicolumn{1}{c}{$\begin{array}{c}\text { Long-Term } \\
\text { Treatment* }\end{array}$} \\
\hline 1 & $0-15$ & $75-100$ & Soil \\
2 & $15-25$ & $40-90$ & Soil \\
3 & $25-40$ & $25-70$ & Very poor rock \\
4 & $40-55$ & $5-30$ & Poor, yet durable rock \\
5 & $55-70$ & $5-15$ & Good to fair rock \\
6 & $70-100$ & $0-10$ & Good to fair rock \\
\hline
\end{tabular}

* "Long-term treatment" is the expected behavior of the material following long-term exposure to weathering.

material in question as "weathered materials" (materials that are moderately strong in the fresh state and that tend to weather into stronger blocks surrounded by weaker matrix materials), or as "weak materials" (materials that are moderately weak in the fresh state and that weather more homogeneously throughout the mass, but with intensity increasing near the ground surface). For weak materials, the weathering grade of the layer or depth in question can be identified (note that because of their natural weakness, even fresh "weak materials" cannot have a weathering grade higher than III). For weathered materials, the proportion of matrix and intact blocks should be estimated (e.g., "30 percent blocks and 70 percent matrix"), and the weathering grade of both components should be estimated (e.g., "matrix is grade VI and blocks are grade III").

Table 4 is used to select four different values describing the critical behavior of a weak or weathered material. The first set is used to select a corestone value (C), to gauge importance of the matrix on the overall behavior. The second set is used to estimate a strength value (S), the third set is used to select the critical aspect of discontinuities controlling the behavior (D), and the fourth set is used to measure the reactivity to water as an indication of the long-term performance of the material (the "rate of change of strength" value, R).

The S-D-R values are then carried to Figure 2 to simultaneously weigh the importance of strength, discontinuities, and changing strength. For example, consider a shale with values from Table 4 of $\mathrm{C}=$ not applicable, $\mathrm{S}=$ $5, \mathrm{D}=1$, and $\mathrm{R}=3$. This material would plot in Region VII on Figure 2, indicating that some strength loss from slaking will occur over time, but not enough to disregard the original strength or the effects of discontinuities.

Additional engineering characteristics can be deduced using previously published correlations to the weathering grade (Table 3). Quantitative values shown in Table 5 were originally determined for weathered granite by Dearman and others (1976), Krank and Watters (1983),

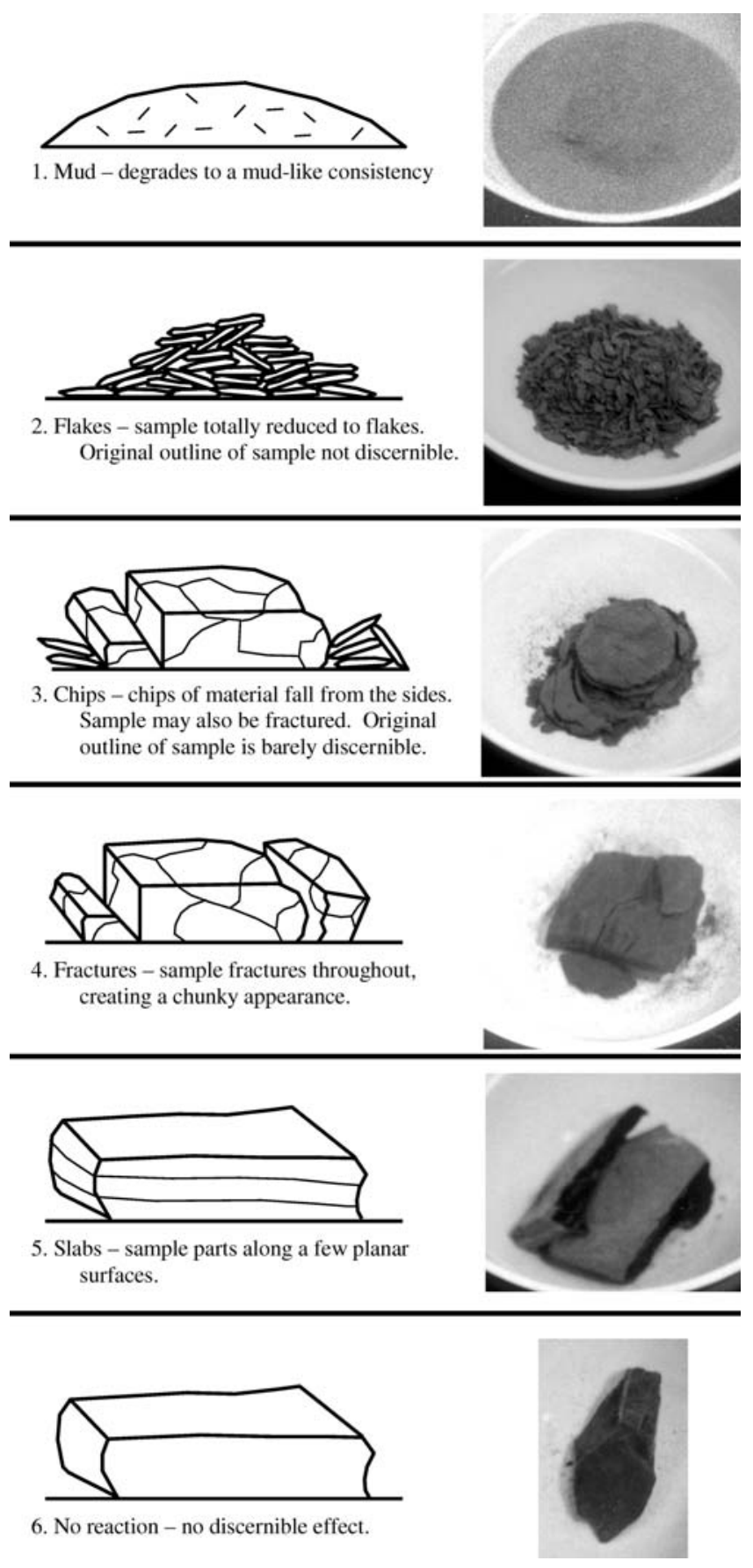

Figure 3. Modified jar slake test categories and descriptions (from Santi, 1998b).

and Lee and de Freitas (1989) and also include correlations for shale and siltstone using data from Santi (1995).

Table 6 shows estimates of slake durability and longterm material behavior based on the R value from Table 4 . These values are based on correlations between the fieldmeasurable $\mathrm{R}$ values and the laboratory slake durability and slake index values (Santi and Higgins, 1998). 
Table 7. Field estimate of permeability (modified from Lee and de Freitas, 1989; and Anonymous, 1977).

\begin{tabular}{|c|c|c|c|}
\hline Class & Description of Absorption & Description of Discontinuities & Estimated Permeability \\
\hline 1 & $\begin{array}{l}\text { Specimen is almost impermeable, most of the } \\
\text { water remains on the surface. }\end{array}$ & No discontinuities & $\leq 10^{-7} \mathrm{~cm} / \mathrm{second}$ \\
\hline 2 & $\begin{array}{l}\text { Specimen is slightly permeable, some water is } \\
\text { absorbed. }\end{array}$ & $\begin{array}{l}\text { Widely to very widely spaced discontinuities } \\
(0.6 \text { to } 6 \mathrm{~m})\end{array}$ & $10^{-5}$ to $10^{-7} \mathrm{~cm} / \mathrm{second}$ \\
\hline 3 & $\begin{array}{l}\text { Specimen is moderately permeable, more than } \\
\text { half of the water is absorbed. }\end{array}$ & $\begin{array}{l}\text { Widely to very widely spaced discontinuities } \\
(0.6 \text { to } 6 \mathrm{~m})\end{array}$ & $10^{-3}$ to $10^{-5} \mathrm{~cm} / \mathrm{second}$ \\
\hline 4 & $\begin{array}{l}\text { Specimen is highly permeable, most of the } \\
\text { water is absorbed. }\end{array}$ & $\begin{array}{l}\text { Close to moderately spaced discontinuities } \\
\text { (6 to } 60 \mathrm{~cm})\end{array}$ & 1 to $10^{-3} \mathrm{~cm} /$ second \\
\hline 5 & - & $\begin{array}{l}\text { Very close to extremely close spaced } \\
\text { discontinuities }(<6 \mathrm{~cm})\end{array}$ & $\geq 1 \mathrm{~cm} / \mathrm{second}$ \\
\hline
\end{tabular}

\section{FIELD TESTING OF WEAK ROCK}

In addition to the estimates of engineering properties that may be made using Tables 4-6, several field tests may be correlated to laboratory tests. For example, Smith (1997) proposes a relationship between Unconfined Compressive Strength (UCS) and the field-derived Point Load Index $\left(I_{\mathrm{s}}\right)$. For stronger rock the UCS is generally 20 to 25 times the $I_{\mathrm{s}}$ (ISRM, 1985). Smith (1997) recognizes that this factor is usually less for weaker materials, so provided the test can be run successfully (that is, with the test failure plane passing through both loading platens), his data may be used to derive the following correlation (UCS and $\mathrm{I}_{\mathrm{s}}$ are both reported in psi units):

$$
\begin{aligned}
U C S & =0.6638 I_{s}{ }_{s}^{1.5857} \\
R^{2} & =0.9712\left(\text { effective for } \mathrm{I}_{\mathrm{s}}<450\right)
\end{aligned}
$$

Smith (1997) also suggests using flat platens over the conical platens on the point load device so that loads will be more broadly distributed and weak materials can be successfully tested.

Slake durability may also be predicted by field tests. Santi and Higgins (1998) provide the following predictive equations for second cycle slake durability, $I_{d}(2)$, based on tests of 100 samples of shale, siltstone, and sandy shale:

$$
\begin{aligned}
\mathrm{I}_{d}(2)= & 16.0(\text { jar slake })-1.7 \quad \mathrm{R}^{2}=0.79 \\
\mathrm{I}_{\mathrm{d}}(2)= & 66.5-3.7(\mathrm{Q})-3.7(\text { hammer rebound }) \\
& +7.2(\text { jar slake })-0.5(\text { slake index }) \\
& \mathrm{R}^{2}=0.85
\end{aligned}
$$

where:

jar slake $=$ rate of change of strength $(\mathrm{R})$ value shown on Table 4.

$\mathrm{Q}=$ Norwegian Geotechnical Institute rock mass classification (Barton et al., 1974). The system integrates both block and discontinuity properties and requires estimates of number of joint sets, joint roughness, joint alteration, joint water, and a stress reduction factor. hammer rebound $=$ number value indicating resistance to blows from a geologic hammer (NAVFAC, 1982):

$1=$ extremely strong (many blows required to break)

$2=$ very strong (more than one blow required to break)

3 = strong (one moderate blow required to break)

$4=$ moderately strong (indents $1-3 \mathrm{~mm}$ with one blow)

$5=$ moderately weak (crumbles with one blow)

$6=$ weak (disintegrates with one blow).

slake index $=$ weight percentage material lost through a \#10 sieve after oven drying and soaking in water (Deo, 1972; Chapman et al., 1976).

Santi (1995) also provides a correlation equation to estimate one-cycle slake index in the field:

$$
\text { slake index }=106.0-18.6(\text { jar slake }) \quad \mathrm{R}^{2}=0.85
$$

Although the jar slake test is convenient to perform in the field, the descriptions for each category are very vague, and as the test is normally performed, readings should be completed at both 30 minutes and 24 hours (Wood and Deo, 1975). This long time period reduces the test's utility as a quick field test. Santi (1998b) showed that for 50 samples classified by 13 different technicians, the 30 minute and 24-hour classifications showed no statistical difference, and the 30-minute test is sufficient. Furthermore, it was shown that by more carefully defining the test categories and providing drawings of samples in each category, included as Figure 3, the consistency between different technicians is greatly improved. Use of the jar slake method shown in Figure 3 produced an average of the standard deviations of results from each sample of 0.39. Using the original jar slake descriptions from Wood and Deo (1975) produced an average of the standard deviations of 0.57 . This is a reduction in the "error" of the test by one-third. 
Finally, a rough estimate of permeability of weak rock (as absorption or as a function of fracture density) may also be made in the field, using Table 7, modified from Anonymous (1977) and Lee and de Freitas (1989). The absorption test, designed for weathered granite blocks, is based on observing the penetration of a few drops of water from a dropper onto a hand specimen, over a period of one minute. The fracture density correlation is intended for rock types where the fractures dominate transport of water, such as fine-grained shales or low porosity rocks.

\section{CONCLUSIONS}

Adequate engineering of shales, weak rock, and weathered rock begins with adequate recognition of potential problems in the field. The tools presented in this paper are intended to help the practitioner recognize potential slaking and reactivity to water, low strength, expected strength loss over time, influence of strong corestones and weak matrix, and expected behavior for various engineering uses. Two field classifications are proposed. The first is a modification of Dearman's Weathering Grade to include shales and other nongranitic rocks. The second system incorporates the modified Dearman scheme and assimilates several existing systems, to indicate proportion of corestones and matrix, strength, influence of discontinuities, and reactivity to water. Finally, several tables and predictive equations will provide the user with a field estimate of unconfined compressive strength, slake durability, slake index, and permeability.

\section{ACKNOWLEDGMENTS}

The author wishes to thank reviewers Lee Abramson, Robert Cummings, and Brian Greene for their helpful comments to improve the manuscript. Any remaining errors are wholly mine.

\section{REFERENCES}

Afrouz, A. A., 1992, Practical Handbook of Rock Mass Classification Systems and Modes of Ground Failure: CRC Press, Boca Raton, FL, $195 \mathrm{p}$.

Anonymous, 1977, The description of rock masses for engineering purposes. Working Party report: Quarterly Journal Engineering Geology, Vol. 10, pp. 355-388.

Barton, N.; Lien, R.; AND Lunde, J., 1974, Engineering classification of rock masses for the design of tunnel support: Rock Mechanics, Vol. 6, No. 4, pp. 189-236.

BIENIAWSKI, Z. T., 1976, Rock mass classification in rock engineering. In Bieniawski, Z.T., ed., Proceedings of the Symposium on Exploration for Rock Engineering: Johannesburg, South Africa, Vol. 1, pp. 97-106.

CaterPillar, 1996, Handbook of Ripping, 10th ed.: Caterpillar, Inc., Peoria, IL, p. 9.

Chapman, D. R.; Wood, L. E.; Lovell, C. W.; and Sisiliano, W. J., 1976, A comparative study of shale classification tests and systems: Bulletin Association Engineering Geologists, Vol. 13, No. 4, pp. 247-266.

DeArman, W. R., 1976, Weathering classification in the characterization of rock: A revision: Bulletin International Association Engineering Geologists, Vol. 13, pp. 373-381.

Dearman, W. R.; Baynes, F. J.; AND Irfan, T. Y., 1978, Engineering grading of weathered granite: Engineering Geology, Vol. 12, pp. 345-374.

Deo, P., 1972, Shales as Embankment Materials: PhD Thesis, Purdue University, $201 \mathrm{p}$.

Geological Society Engineering Group Working Party, 1995, The description and classification of weathered rock for engineering purposes: Quarterly Journal Engineering Geology, Vol. 28, No. 3, pp. 207-242.

Hatheway, A. W., 1997, Origin and formation of weak-rock masses: A guide to field work. In Santi, P. M. and Shakoor, A. (Editors), Characterization of Weak and Weathered Rock Masses, Association of Engineering Geologists Special Publication \#9: Association of Engineering Geologists, Denver, CO, pp. 23-36.

INTERNATIONAL SOCIETY FOR Rock Mechanics (ISRM), 1985, Suggested method for determining point load strength: International Journal Rock Mechanics Mineral Science Geomechanical Abstracts, Vol. 22, No. 2, pp. 51-60.

KRANK, K. D. AND WatTers, R. J., 1983, Geotechnical properties of weathered Sierra Nevada granodiorite: Bulletin Association Engineering Geologists, Vol. 20, No. 2, pp. 173-184.

LeE, S. G. AND de Freitas, M. H., 1989, A revision of the description and classification of weathered granite and its application to granites in Korea: Quarterly Journal Engineering Geology, Vol. 22, No. 1, pp. 31-48.

NAVFAC, 1982, Design Manual 7.1: Soil Mechanics: Department of the Navy, Naval Facilities Engineering Command, Alexandria, $\mathrm{VA}, 360 \mathrm{p}$.

PALICKI, K. S., 1997, A graphical method for the classification of rock and weak rock masses based on field observations: Engineering Environmental Geoscience, Vol. 3, No. 1, pp. 7-12.

SANTI, P. M., 1995, Classification and Testing of Weak and Weathered Rock Materials: A Model Based on Colorado Shales: Unpublished $\mathrm{PhD}$ dissertation, Colorado School of Mines, Golden, $\mathrm{CO}, 286 \mathrm{p}$.

SANTI, P. M., 1997, Comparison of weak and weathered rock classification systems. In Santi, P. M. and Shakoor, A. (Editors), Characterization of Weak and Weathered Rock Masses, Association of Engineering Geologists Special Publication \#9: Association of Engineering Geologists, Denver, CO, pp. 139-160.

SANTI, P. M., 1998a, Refined field methods for identifying, describing, and testing shale and weak rock. In Proceedings of the Ohio River Valley Soils Seminar XXIX, Louisville, KY, 15 p.

SANTI, P. M., 1998b, Improving the jar slake, slake index, and slake durability tests for shales: Environmental Engineering Geoscience, Vol. 4, No. 3, pp. 385-396.

Santi, P. M. AND Doyle, B. C., 1997, The locations and engineering characteristics of weak rock in the U.S. In Santi, P. M. and Shakoor, A. (Editors), Characterization of Weak and Weathered Rock Masses, Association of Engineering Geologists Special Publication \#9: Association of Engineering Geologists, Denver, CO, pp. 1-22.

SAnti, P. M. ANd Shakoor, A., 1997, Summary of pre-symposium questionnaire. In Santi, P. M. and Shakoor, A. (Editors), Characterization of Weak and Weathered Rock Masses, Association of Engineering Geologists Special Publication \#9: Association of Engineering Geologists, Denver, CO, pp. 225-233.

SAnTi, P. M. AND Higgins, J. D., 1998, Methods for predicting shale 
durability in the field: ASTM Geotechnical Testing Journal, Vol. 21, No. 3, pp. 195-202.

Sмiтн, H. J., 1997, Assessing weak rock excavatability: Site characterization and predictive techniques. In Santi, P. M. and Shakoor, A. (Editors), Characterization of Weak and Weathered Rock Masses, Association of Engineering Geologists Special Publication \#9: Association of Engineering Geologists, Denver, CO, pp. 203-223.

Sowers, G. F, 1973, Settlement of waste disposal fills. In Proceedings of the 8th International Conference on Soil Mechanics and Foundation Engineering, Moscow, ID, pp. 207-210.

UNDERWOOD, L. B., 1967, Classification and identification of shales: Journal Soil Mechanics Foundations Division, ASCE, Vol. 93, No. SM-6, pp. 97-116.
Welsh, R. A.; Vallejo, L. E.; Lovell, L. W.; and Robinson, M. K., 1991, The U.S. Office of Surface Mining (OSM) proposed strength-durability classification system: In Kane, W. F. and Amadei, B. (Editors), Detection of and Construction at the Soill Rock Interface, ASCE Geotechnical Special Publication No. 28: ASCE, New York, pp. 125-140.

White, R. M. and Richardson, T. L., 1987, Predicting the difficulty and cost of excavation in the Piedmont. In Smith, R. E. (Editor), Foundations and Excavations in Decomposed Rock of the Piedmont Province: ASCE Geotechnical Special Publication No. 9: ASCE, New York, pp. 15-36.

Wood, L. E. And Deo, P., 1975, A suggested system for classifying shale materials for embankments: Bulletin Association Engineering Geologists, Vol. 12, No. 1, pp. 39-55. 